\title{
Influence of leaflet age in anatomy and possible adaptive values of the midrib gall of Copaifera langsdorffii (Fabaceae: Caesalpinioideae)
}

\author{
Denis Coelho de Oliveira ${ }^{1} \&$ Rosy Mary dos Santos Isaias ${ }^{1,2}$ \\ 1. Universidade Federal of Minas Gerais, Institute of Biological Sciences, Department of Botany, Laboratory of Plant \\ Anatomy, Belo Horizonte, MG, Brazil. \\ 2. corresponding author: rosy@icb.ufmg.br
}

\author{
Received 21-XI-2007. Corrected 10-VII-2008. Accepted 13-VIII-2008.
}

\begin{abstract}
Gall inducing insects most frequently oviposit in young tissues because these tissues have higher metabolism and potential for differentiation. However, these insects may also successfully establish in mature tissues as was observed in the super-host Copaifera langsdorffii. Among C. langsdorffii gall morphotypes, one of the most common is a midrib gall induced by an undescribed species of Cecidomyiidae. Following this 'host plant and gall-inducing insect' model, we addressed two questions: 1) Do the age of the tissues alter the gall extended phenotype? 2) Do gall morphological and anatomical features influence the adaptive value of the galling insect? For anatomical and histometrical studies, transverse sections of young and mature, galled and ungalled samples were prepared. Galls in young leaflets presented higher potential for cell division and greater nutritive reserves, whereas galls in mature leaflets perhaps provide more protection against natural predators and desiccation. Host organ age at the time of oviposition may influence plant cell fates and consequently the interpretation of the adaptive value of insect galls. Rev. Biol. Trop. 57 (1-2): 293-302. Epub 2009 June 30.
\end{abstract}

Key words: Brazil, Cecidomyiidae, leaf anatomy, host organ maturity, Fabaceae, gall-inducing.

Entomogenous galls are originated by abnormal cell development in host species organ regulated by the action of a parasitic insect, which obtains directly or indirectly, shelter, food, and protection (Rohfritsch 1992, Isaias 1998). Galls can be interpreted as adaptations of some insects seeking high quality food, and protection against natural enemies or abiotic factors (Price et al. 1986), but extremely dependent on continuous chemical and alimentary activity of the insect (Mani 1964, Meyer \& Maresquelle 1983, Bronner 1992).

The specificity of the galling insects to their host plant and organ are so strict that they are able to induce galls in only one or in a group of related host plant species (DregerJauffret \& Shorthouse 1992, Nyman 2000, Stone \& Schönrogge 2003, Inbar 2004).
Through the induction of galls, the insects are capable of inducing morphogenetic changes in the host plant that are at first directed against them, but that they afterwards manipulate and use for food or for shelter (Edwards \& Wratten 1981, Redfern \& Askew 1992, Rohfritsch 1992). Galling insects are sensitive to discrete physiological, chemical, and phenological changes during their host plant development (Floate et al. 1996). Consequently, the age of the tissues by the time of oviposition can alter the patterns of anatomical development and the adaptive value of the gall.

Immature tissues usually possess larger concentration of hormones when compared to mature ones (Buchanan et al. 2000), thus young tissues are more capable of responding to external stimuli. Besides, plant hormones 
concentration is higher in gall tissues than in their host organ, nevertheless these substances seem to be relocated to the galling site from the ungalled plant parts (Leitch 1994).

Because galls are formed through cell hypertrophy, tissue hyperplasia, developmental inhibition or cytological changes in response to the attack of the galling organisms (Mani 1964), it seems clear that the mechanisms of growth activation or inhibition should be related to hormonal balance under the influence of the continuous feeding activity of the insect (Fosket 1994, Hartley 1998).

Independently of the type or the origin of the stimuli, insect galls are of common occurrence in botanical families of great morphological variability and wide distribution, such as the Fabaceae.

One of the most common gall morphotype observed in Copaifera langsdorffii Desf. is a leaf midrib swelling induced by an undescribed species of Diptera: Cecidomyiidae in young and mature leaflets. Once host tissues age by the time of the galling larvae establishment can influence on the degree of cell hypertrophy and tissue hyperplasia observed, and these alterations can be used to indicate the adaptive value of the gall for the galling insect, the objectives of this work were to draw histological parameters that can be used to differentiate galls induced in young leaves from those induced in mature ones, and also evaluate the anatomical features related to the adaptive value of the gall for the galling insect nutrition, and protection against natural enemies or abiotic features.

\section{MATERIAL AND METHODS}

Galled and ungalled, young and mature leaflets were collected monthly, from September, 2006 to September, 2007, from 5 specimens of a population of Copaifera langsdorffii Desf. (Fabaceae: Caesalpinioideae) located at an area of canga at Retiro das Pedras $\left(20^{\circ} 05^{\prime} 35\right.$ "S, 4359'01 "W), Serra da Calçada, municipal district of Brumadinho-MG (Fig. 1). Canga is a type of savannah with predominant herbaceous vegetation growing in very nutrient-poor soils (Silva et al. 1996).
For structural studies, histological sections of young and mature ungalled leaflets, and mature galls induced either in young or mature leaflets were prepared. The maturity of ungalled leaflets was defined by their color, width and length, while the maturity of the galls was defined by their maximum length plus the presence, color and length of the larvae. For histological studies, transverse sections from samples previously fixed in FAA (Johansen 1940), dehydrated in n-butyl series, and embedded in Paraplast ${ }^{\circledR}$ (Kraus \& Arduin 1997) were prepared. All the samples were sectioned ( $8-12 \mu \mathrm{m}$ of thickness) and stained with $0.5 \%$ astra blue and $0.5 \%$ safranina $(8: 2$ v/v) (Bukatsch 1972, modified).

The length and width of the galled leaflets $(\mathrm{n}=40)$, and the length of the galls $(\mathrm{n}=$ 40) were measured with the aid of a digital caliper.

Histometrical analyses were accomplished in transverse sections. The analysis of cell area and number of cells per area were performed in five samples of each material: young ungalled leaflets (YL), mature ungalled leaflets (ML), galls induced on young leaflets (YLG), and galls induced in mature leaflets (MLG). Cell areas of palisade and spongy parenchyma of ungalled leaflets $(n=40$ fields), reserve and nutritive parenchyma of the galls $(n=40$ fields), and the length of the larvae in YLG $(\mathrm{n}=30)$ and in MLG $(\mathrm{n}=30)$ were measured with the aid of a clear camera coupled to a light microscope and submitted to the Quantikov Image Analyzer ${ }^{\circledR}$.

All data were submitted to the ANOVA, followed by the Tukey test (5\%). The photomicrographs were obtained at a light photomicroscope from slides mounted with vitral lacquer Acrilex $^{\circledR}$ (Paiva 2006).

\section{RESULTS}

The midrib gall of Copaifera langsdorffii was formed by a swelling of the central portion of leaflet lamina, with an ostiole placed along the whole extension of the gall (Fig. 2a). This gall morphotype might occur in young and 

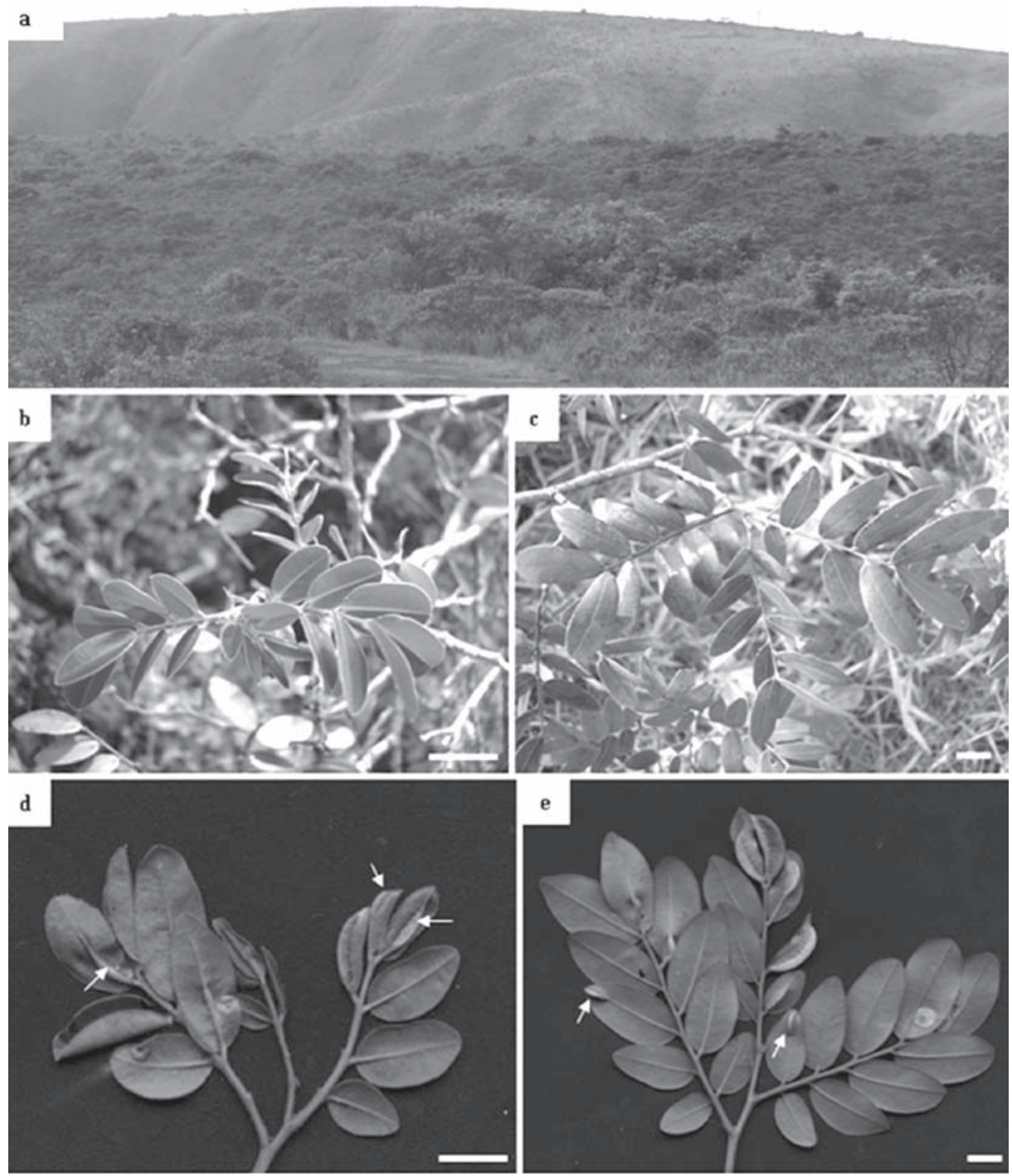

Fig. 1a - e. a) Population of Copaifera langsdorffii located in an area of canga. b) Young leaves. c) Mature leaves. d) Galls (arrows) induced in young leaflets. e) Galls (arrows) induced in mature leaflets. Bars $=10 \mathrm{~mm}$.

mature leaflets (Fig. 2b, c). The young leaflets collected were red, smaller, and membranaceous while mature leaflets were dark green, larger, and coriaceous (Figs. 2b, 3a, b). YLG and MLG insignificantly differed in their size and shape (Fig. 3c). Galling insects of YLG and MLG were at the same larval stage, which could be inferred by the similarity in color, length (Fig. 3d), and bodies shape.
Epidermis either of YL or ML was unisseriate, composed of rectangular cells in transverse section, but covered by a thicker cuticle in ML. Trichomes were observed all along the midrib in YL, but were totally absent in ML.

In YL, the mesophyll was homogeneous, but it was possible to distinguish the layers of cells that would originate the spongy parenchyma. The ground system of ML was 
a
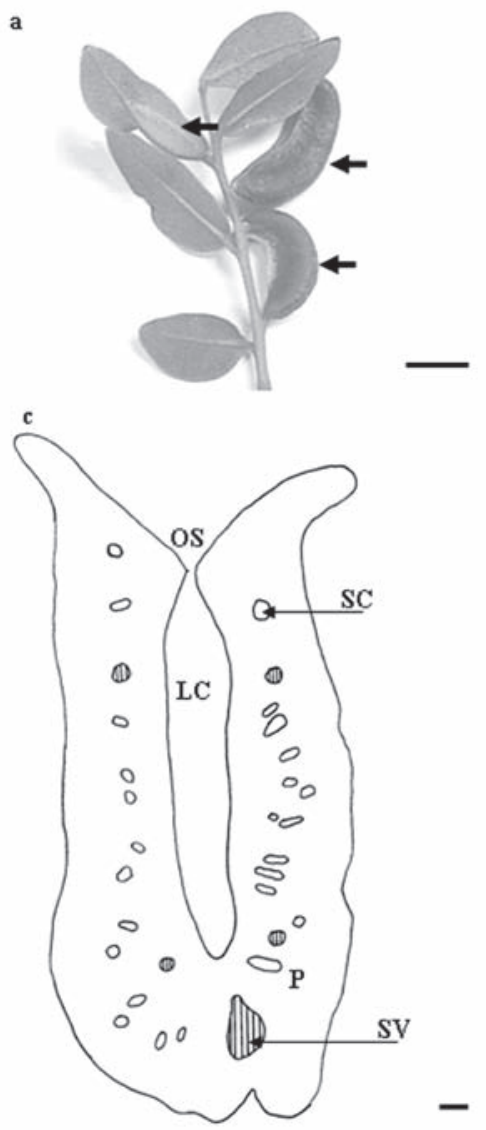

b
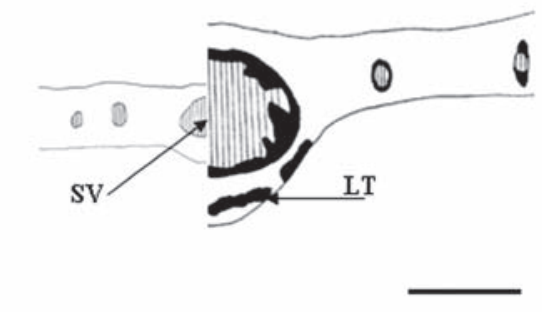

d

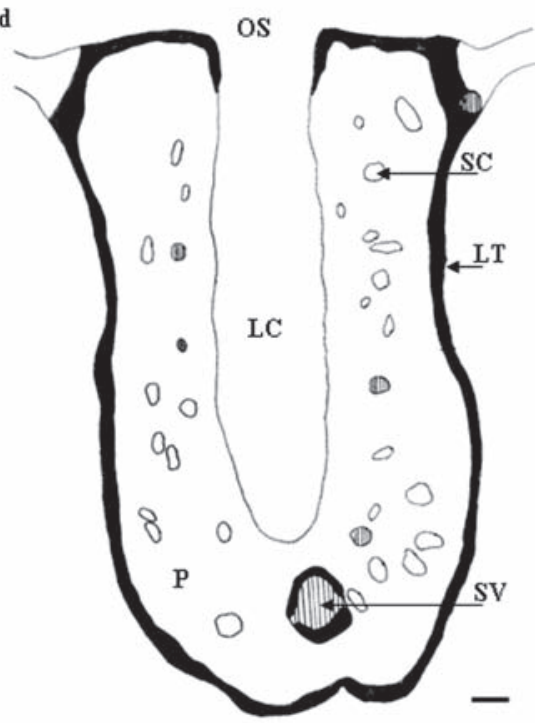

Fig. 2a - d. a) Galls (arrows) induced on leaflets of Copaifera langsdorffii . b) Comparative diagram of young (left) and mature (right) leaflets. c) Diagram of gall induced on young leaflet. d) Diagram of gall induced in mature leaflet. $(\mathrm{P}=$ parenchyma, $\mathrm{SC}=$ secretory cavities, $\mathrm{VS}=$ vascular system, $\mathrm{LC}=$ larval camera, $\mathrm{OS}=$ ostiole, $\mathrm{LT}=$ lignified tissue). Bars in fig. $1 \mathrm{a}=10 \mathrm{~mm}$, in fig. $1 \mathrm{~b}-\mathrm{d}=100 \mu \mathrm{m}$.

constituted of $1-2$ layers of palisade and of 2 -3 of spongy parenchyma with secretory cavities interspersed between them, either in YL or ML. The midrib vascular system was collateral in organization. In YL, the vascular system is poorly developed, the vessel elements were thin-walled and the periciclic fibers were not lignified yet (Fig. 2b). In ML, the vessel elements were thick-walled and outlined by lignified periciclic fibers (Fig. 2b).

Epidermis of YLG was unisseriate with isodiametric and rectangular cells in transverse section, turning into papilose ones and covered with a slightly more thickened cuticle at the ostiolar region (Fig. 4a). MLG epidermal cells were remarkably more papilose and sharper, covered with thicker cuticle at the ostiolar region when compared to YLG (Fig. 4b).

The ground system of YLG and MLG presented a distinct zonation of tissues. The initial palisade parenchyma cell layers differentiated gall nutritive tissue; whereas the initial abaxial spongy parenchyma cells differentiated the gall reserve tissue (Fig. 4c). In MLG, the two cell layers adjacent to the abaxial epidermis and the $2-3$ cells close to the ostiole lignified (Fig. 4d). 

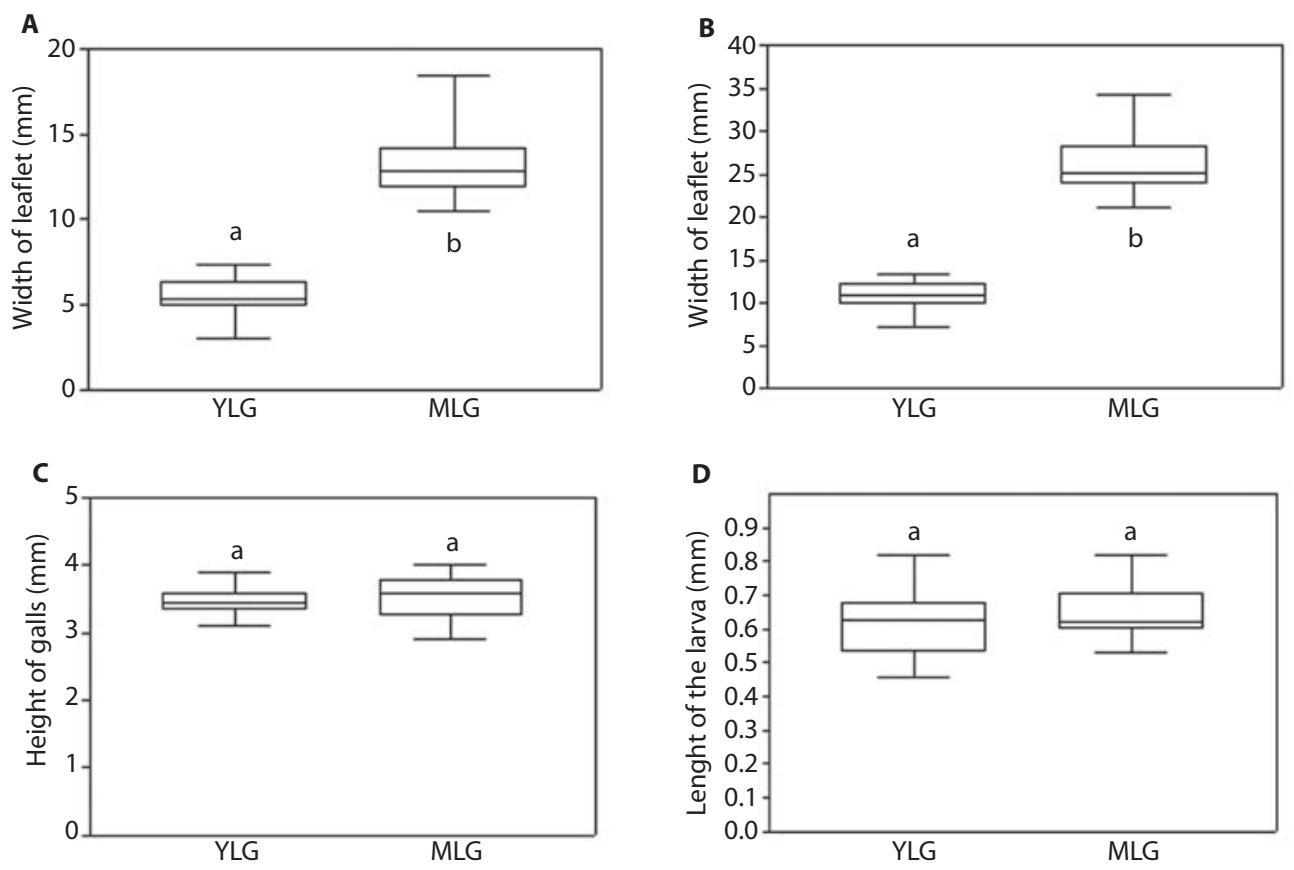

Fig. $3 \mathrm{a}-\mathrm{d}$. Morphometrical analyses of the leaflets and galls of Copaifera langsdorffii. a) Width of ungalled leaflet. b) Length of ungalled leaflet. c) Width of galls induced in young and mature leaflets. d) Length of the larva from galls induced in young and mature leaflets. ( $\mathrm{YL}=$ young leaflet, $\mathrm{ML}=$ mature leaflet, $\mathrm{GYL}=$ gall on young leaflet, $\mathrm{GML}=$ gall on mature leaflets). Distinct letters indicated significant differences by the Tukey's test $(\mathrm{P}<0,05)$.

In YLG, this lignification did not occur (Fig. 4c). The number of secretory cavities in YLG was higher than in MLG.

Vascular bundles malformation and scarce xylem differentiation were observed in YLG (Fig. 4e), while in MLG, vascular bundles remained unaffected (Fig. 4f).

The number of cell layers per area in transverse section was practically the same either in YLG or in MLG. In YLG, the number of cells in the transverse section was significantly higher than those of MLG (Fig. 5a).

The mesophyll in ML was thicker than that of YL, however the mesophyll of YLG was significantly thicker than that of MLG (Fig. 5b). In YL, the area of palisade parenchyma cells in transverse section was reduced when compared to that of ML. In relation to the spongy parenchyma, cells hypertrophied (Fig. 5c). In YLG, the area of the reserve parenchyma cells was smaller than that of the MLG. However, the area of the cells in the YLG nutritive tissue as well as that of MLG did not differ significantly (Fig. 5d).

\section{DISCUSSION}

Variations in gall structure were usually related to their age. Based on 1-year field observations on C. langsdorffii galls development, young midrib galls induced in young and mature leaftlets were observed (Drummond 2005). In this research, adding data to field observation, the midrib galls induced by an undescribed species of Diptera: Cecidomyiidae in young and mature leaflets of Copaifera langsdorffii were considered in the same developmental stage, by checking the larval instar, and gall dimensions. 

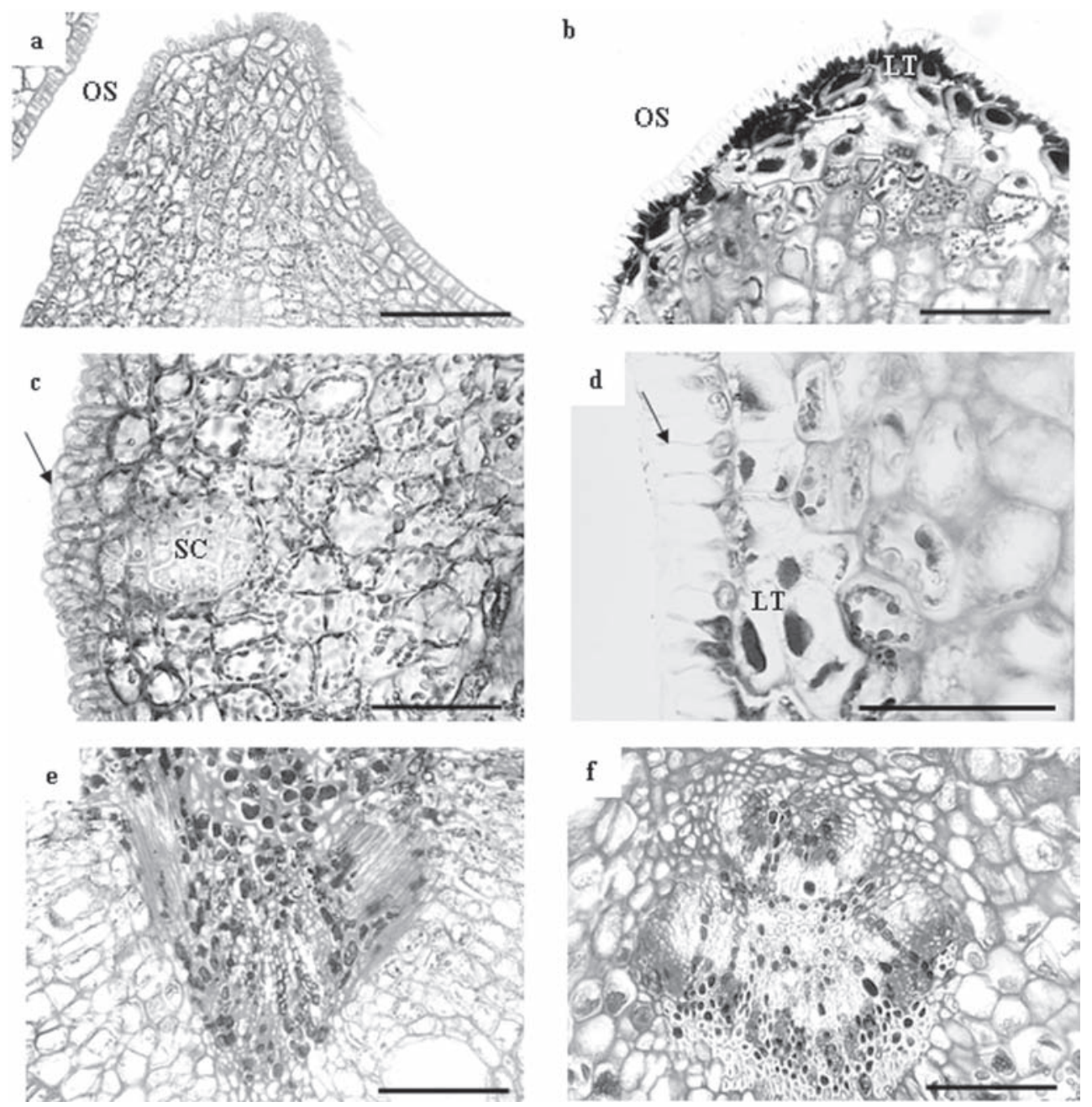

Fig. $4 \mathrm{a}-\mathrm{f}$. Galls of Copaifera langsdorffii. a) transverse sections of young leaflet gall ostiole. b) transverse sections of mature leaflet gall ostiole. c) external portion of the gall induced in young leaflets. d) External portion of the gall induced in mature leaflets showing epidermal cells in drop shape and lignification of cell layer adjacent to the abaxial epidermis. e) midrib of young leaftlet gall. F, midrib of mature leaftlet gall. Bars $=100 \mu \mathrm{m}$.

According to Rohfritsch (1992), young tissues were generally more capable of reacting to gall induction than mature ones. Nevertheless, this is not an exclusive condition. In the studied population of $C$. langsdorffii, Cecidomyiidae galls were equally observed either on young or mature leaflets, similarly to the observations of Arduin and Kraus (1995) in leaves of Piptadenia gonoacantha (Mart.) J.F. Macbr., and of Souza et al. (2000) in leaves of Ficus microcarpa L. f. (Moraceae).
Leaf tissues did not fuse along during the midrib gall development, and so the galling insect larvae were partially exposed to the external environment all the time. According to Edwards and Wratten (1980), gall inducing insects usually oviposit on the abaxial leaf surface, because this site provides more appropriate and less stressful microclimatic conditions than the adaxial surface. So, the success of the midrib gall Cecidomyiidae, which oviposited in the adaxial surface, should be guaranteed by the 
A
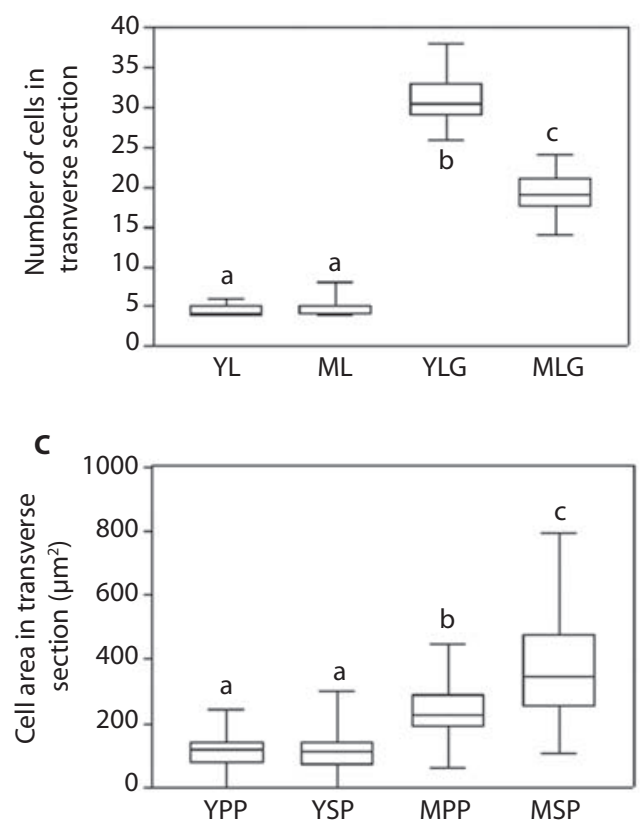

B
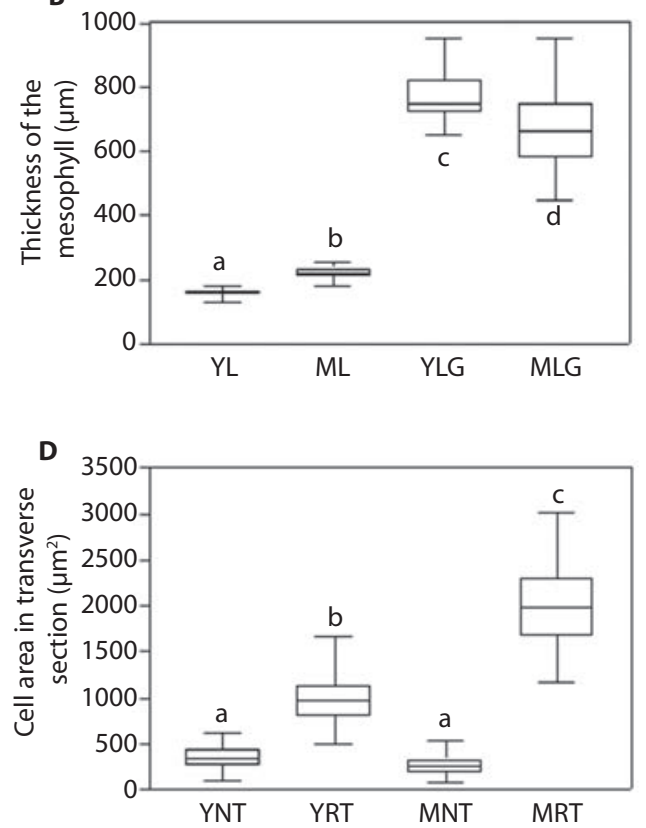

Fig. 5a-d. Histometrical analyses in ungalled leaflets and galls of Copaifera langsdorffii. a) number of cells in transverse section in young and mature leaftlets and galls induced in young and mature leaflets. b) thickness of the mesophyll of young and mature leaflets and galls induced in young and mature leaflets. c) cell area of palisade and spongy parenchyma in transverse section in young and mature leaflets. d) cell area of the reserve and nutritive tissues of galls induced in young and mature leaflets in transverse section. ( $\mathrm{YL}=$ young leaflet, $\mathrm{ML}=$ mature leaflet, $\mathrm{YGL}=$ galls on young leaflet, GML = galls on mature leaflet, YPP = young palisade parenchyma, YSP = young spongy parenchyma, MPP = mature palisade parenchyma, MSP = mature spongy parenchyma, YNT = gall nutritive tissue on young leaflet; YRT = gall reserve tissue on young leaflet; $\mathrm{MNT}$ = gall nutritive tissue on mature leaflet; MRT = gall reserve tissue on mature leaflet). Distinct letters indicated significant differences by the Tukey's test $(\mathrm{P}<0.05)$.

gall cells thicker wall and cuticle, which should maintain temperature and humidity in leaf surface (Fahn 1990, Woodman \& Fernandes 1991, Gutschick 1999, Press 1999). Thus, the higher cuticular thickening in MLG could guarantee more efficient protection against desiccation.

Maturation of the ground system cells in ungalled leaflets revealed the differentiation of palisade and spongy parenchyma due to cell hypertrophy and differentiation. In MLG, the two layers of cells just below the epidermis lignified, a feature not observed in YLG even after insects emergence. These differences could positively influence the adaptability of the gall to the galling insect against predators and parasitoids mainly in the MLG, as pointed out by Weis et al. (1998), Nyman (2000), and Stone and Schönrogge (2003). The lignification of the internal layers of MLG could be related to the protection of the galling insect against natural enemies. So, YLG would be more susceptible to the action of natural predators, what could be proved by the comparative evaluation of the guild of predators in young and mature leaflets. However, neither of these evaluations were performed nor there were data in literature about the evaluation of the impact of predators and parasitoids in galls induced in young and mature leaflets.

The general premise that relates lignification to protection was reinforced in C. langsdorffii-Cecidomyiidae model. Nevertheless, 
according to Stone and Schönrogge (2003), while galls external structure diversification has been related to defense, internal structure diversification has probably been related to an increase in nutritious supply. In fact, in YLG, the increase in the number of cell layers could improve nutritious supply, but in MLG, the lignification of internal cell layers could be mainly related to protection. So, distinct degrees of adaptability of the gall to the galling insect could vary in function of the age of the tissues by the oviposition time.

In C. langsdorffii, the nutritive tissue maintained the same characteristics either in YLG or MLG, which could be related to the maintenance of the cells high metabolic activity due to the feeding activity of the larvae (Bronner 1992, Vechi 2004) independently of the age of the host organ. In YLG, the increase in cell number and consequent decrease in cell area of reserve tissue indicated a larger potential for cell division. This feature was also noted by the larger amount of secretory cavities. Conclusively; these gall tissues are in process of cell expansion and differentiation, with their meristematic activity potentialized for the galling insect activity. This potentialization could confer the greater investment in nutritive resources in YLG. Also, the significant difference in the number of cells between YLG and MLG was a clear indicative that oviposition occurred in different stages of leaflet maturity.

Due to the feeding activity of the galling insect, vascular bundles malformation and the scarce xylem differentiation was observed in the vascular system of YLG. The inhibition in vascular system development and the collapse of protoxylem cells of young galls, in general, could happen in function of cell hypertrophy and tissue hyperplasia, as proposed by Souza et al. (2000). In MLG, vascular bundles were unaffected, probably due to the end of procambium maturation by the time of ovipositon.

Experimental evidences indicated that the galling insect manipulated the allocation of host plant resources in its own advantage. Galling insects could cause the concentration of nutrients and metabolites in gall tissues by the elevation of the photosynthetic yield in the host organs or by the mobilization of the organ or neighboring tissues reserves (Whitham 1992, Fay 1993, Nyman 2000, Stone \& Schönrogge 2003). Gall induction in young leaflets could favor the galling insect mainly in what nutrition and photoassimilates allocation for tissue development was concerned. The physiological youth of ungalled leaflets, which function as sinks, could prompt better nutrition to the galling insect.

Either young or mature tissues respond to the galling insect activity in $C$. langsdorffii. In young tissues, the cecidogenic responses were wider and faster, once the cells were less differentiated, and with larger capacity for division, similarly to Souza et al. (2000) observations in galls induced in young leaves of Ficus microcarpa.

The physiological youth of the host organ could cause a significant impact in gall anatomy and in the adaptability of gall structure for the galling insect, nevertheless galls were commonly interpreted as extended phenotypes of the galling insects, and then the morphological diversity was expressed around the fitness of the galling insects (Stone \& Cook 1998, Stone \& Schönrogge 2003). The anatomical differences observed in YLG and MLG of $C$. langsdorffii were influenced by the degree of maturity of the host tissues, and these can also be related to the adaptive value of the gall for the galling insect.

Even though the phenotypes of YLG and MLG were similar, the anatomical patterns were dependent on the capacity of cell differentiation in young and mature leaflets. These alterations could be mainly related to the increase in nutritive reserves in YLG, with the protection against natural predators, and desiccation in MLG.

The histological pattern of YLG indicated a tendency for the restarting of new cell cycles in mesophyll, while in MLG, the limited number of cell layers and cell lignification in certain sites confirmed the tendency for the end of cell cycles. Nevertheless, in both gall types cell re-differentiation cycles ended up because of 
the metabolic decline of the galls associated to the galling insects emergence.

This study showed new perspectives for ecological and evolutionary studies of galls induced in young and mature tissues and the way they distinctly influence the corroboration of the nutrition and protective hypotheses at the same host plant and galling insect system. Also it showed that in structural studies the maturity of the host organ by the oviposition time could influence the results and the consequent interpretation of the adaptive value of the galls for the inducer.

\section{ACKNOWLEDGMENTS}

The authors thank CAPES and FAPEMIG (CBB 782/06) for financial support.

\section{REFERENCES}

Arduin M., \& J.E. Kraus. 1995. Anatomia e ontogenia de galha foliares de Piptadenia gonoacantha (Fabales, Mimosaceae). Bol. Bot. Univ. São Paulo 14: 109130.

Bronner, R. 1992. The role of nutritive cells in the nutrition of cynipids and cecidomyiids, p. 118-140. In J.D. Shorthouse \& O. Rohfritsch, (eds.). Biology of Insect Induced Galls. Oxford University Press, New York, New York, USA.

Buchanan, B.B., W. Gruissem, \& R.L. Jones. 2000. Biochemistry and molecular biology of plants. American Society of Plant Physiology, Rockville, Maryland, USA.

Bukatsch F. 1972. Bermerkungen zur Doppelfärbung Astrablau-Safranin. Mikrokosmos 61: 255.

Dreger-Jauffret, F. \& J.D. Shorthouse. 1992. Diversity of gall-inducing insect and their galls. p. 8-33. In J.D. Shorthouse \& O. Rohfritsch, (eds.). Biology of Insect Induced Galls. Oxford University, New York, New York, USA.

Drummond, M.M. 2005. Galhas entomógenas em Copaifera langsdorffii Desf. (Fabaceae), estrutura anatômica, histoquímica e sazonalidade. Dissertação de Mestrado. Universidade Federal de Minas Gerais. Brazil.

Edwards, P.J. \& Wraten, S.D. 1981. Ecologia das Interações Entre Insetos e Plantas. Editora da Universidade de São Paulo, São Paulo, São Paulo, Brasil.

Fay, P.A., D.C. Hartnett, \& A.K. Knapp. 1996. Plant tolerance of gall-insect attack and gall-insect performance. Ecology 77: 521-534.

Fahn, A. 1990. Plant Anatomy. Pergamon Press, Oxford, Oxford, UK.

Floate, K.D., G.W. Fernandes, \& J. Nilsson. 1996. Distinguishing intrapopulational categories of plants by their insect faunas: galls on rabbitbrush. Oecologia 105: 221-229.

Fosket, D.E. 1994. Plant Growth and Development. A Molecular Approach. Academic Press, San Diego, California, USA.

Gutschick, V.P. 1999. Research reviews: biotic and abiotic consequences of differences in leaf structure. New Phytol. 14: 3-18.

Hartley, S.E. 1998. The chemical composition of plant galls: are levels of nutrients and secondary compounds controlled by the gall former? Oecologia 113: 492-501.

Inbar, M., M. Wink, \& D. Woll. 2004. The evolution of host plant manipulation by insects: molecular and ecological evidence from gall-forming aphids on Pistacia. Mol. Phyl. Evol. 32: 504-511.

Isaias, R.M.S. 1998. Galhas Entomógenas em Machaerium (Leguminosae-Papilionoidae): Anatomia e Histoquímica. Ph. D . Thesis. Universidade de São Paulo, São Paulo, Brazil.

Johansen, D.A. 1940. Plant Microtechnique. McGraw-Hill Book, New York, New York, USA.

Kraus, J.E. \& M. Arduin. 1997. Manual Básico de Métodos em Morfologia Vegetal. Editora da Universidade Federal Rural do Rio de Janeiro, Seropédica, Rio de Janeiro, Brasil.

Leitch, I.J. 1994. Induction and developmental of bean gall caused by Pontania proxima. p. 283-300. In M.A.J. Williams (ed.). Plant Gall: Organisms Interaction, Population. Oxford University Press, New York, New York, USA. 
Mani, M.S. 1964. Ecology of Plant Galls. Dr. W. Junk Publishers, The Hague, Neetherlands.

Meyer, J. \& H.J. Maresquelle. 1983. Anatomie des Galles. Gebrüder Borntraeger, Berlin, Berlin, Deutsch.

Nyman, T. 2000. Phylogeny and Ecology Evolution of Gallinducing Sawflies (Hymenopetra: Tenthredinidae). $\mathrm{Ph}$. D Dissertations in Biology.University of Joensuu, Joensuu, Finland.

Paiva, J.G.A. 2006. Verniz vitral incolor $500^{\circledR}$ : uma alternativa de meio de montagem economicamente viável. Acta Bot. Bras. 20: 257-264.

Press, M.C. 1999. The functional significance of leaf structure: a search for generalizations. New Phytol. 143: $213-230$.

Redfern, M. \& R.R. Askew. 1992. Plant Galls. Richmond Publishing Co. Slough, England, UK.

Rohfritsch, O. 1992. Patterns in gall development. p. 60-86. In J.D. Shorthouse and O. Rohfritsch, (eds.). Biology of insect induced galls. Oxford University, New York, New York, USA.

Rohfritsch, O. \& M. Anthony. 1992. Strategies on gall induction by two groups of homopterans. p. 102-117. In J.D. Shorthouse and O. Rohfritsch, (eds.). Biology of insect induced galls. Oxford University, New York, New York, USA.
Silva, M.F.F., R.S. Secco, \& M.G.A. Lobo. 1996. Aspectos ecológicos da vegetação rupestre da Serra do Carajás. Acta Amazon. 26: 17-44.

Souza, S.C.P.M., J.E. Kraus, R.M.S. Isaias, \& L.J. Neves. 2000. Anatomical and ultrastructural aspects of leaf galls in Ficus microcarpa L. F. (Moraceae) induced by Gynaikothrips ficorum Marchal (Thysanoptera). Acta Bot. Bras. 14: 57-69.

Stone, G,N. \& J.M. Cook. 1998. The structure of cynipid oak galls: patterns in the evolution of an extended phenotype. Proc. R. Soc.London B 265: 979-988.

Stone, G.N. \& K. Schönrogge. 2003. The adaptive significance of insect gall morphology. Trends Ecol. Evol. 18: $512-577$.

Vecchi, C. 2004. Reações diferenciais a herbívoros galhadores em espécies de Melastomataceae. Ph. D. Thesis, Universidade de São Paulo, São Paulo, Brasil.

Whitham, T.G. 1992. Ecology of Pemphigus gall aphids. p. 225-237. In J.D. Shorthouse \& O. Rohfritsch, (eds.). Biology of Insect Induced Galls. Oxford University, New York, New York, USA.

Woodman, R.L. \& G.W. Fernandes. 1991. Differential mechanical defense: herbivory, evapotranspiration, and leaf-hairs. Oikos 60: 11-19. 